\author{
تأملى بر مهارتهاى روششناسى بُزوهش در دانشجويان كارشناسىارشد \\ رشته هاى علوم انسانى: يافته هاى يك مطالعه آميخته
}

\title{
Reflection on the Research Methodological Skills of Master Students in Human Sciences disciplines: mixed method study
}

\section{H. ZeinAbadi (Ph. D), M.Ghalvazi}

Abstract: Current study has been implemented with the aim of quality evaluation of research methodological skills of master students in human science disciplines in Tehran's public Universities. In qualitative section, by using purposeful and snow-ball sampling, experts in field of teaching methodology were interviewed. By using content analysis and coding procedure and also the syllabuses of the research methods and statistic courses, 35 important skills were indentified. In quantitative section, based on identified skills a valid and reliable questionnaire was developed and completed by 270 students. First, by implementing exploratory factor analysis, all skills were decreased into 27 skills and 4 factors (designing, practical, analytical and writing skills) were indentified. In the second stage, confirmatory factor analysis revealed that the measurement model of latent variable has good fit with observed data. In the next stage the results of Chi-squared test indicated that students have meaningful evaluation from skills. They evaluated their skills lower than average. Also the results of Friedman test have meaningfully ranked skills in each dimension. The results of ranked skills indicate that "selecting an appropriate title for doing research", "using electronic resource and scientific database", "interpreting the outputs of analyzed data", and "writing an article from the results of conducted research" have the lowest rank in each dimension. Generally, result of this study indicates weakness in needed research skills among human sciences master students of Tehran's public Universities.

Keywords: Research Methodology, Graduate Students, Human Science Disciplines, Skill, Mixed Method.

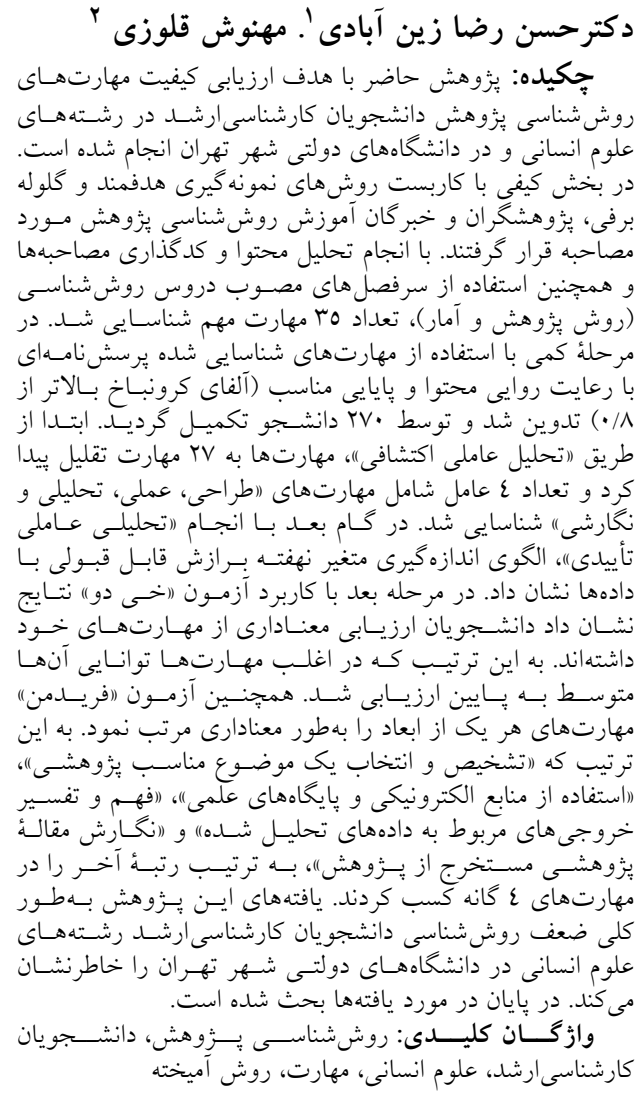

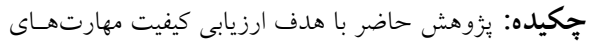

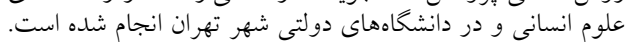

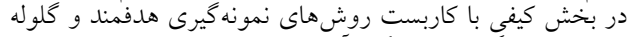

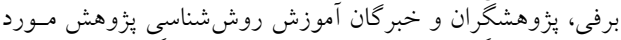

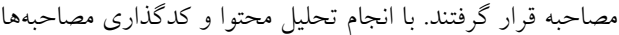

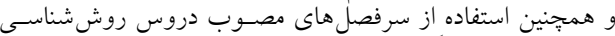

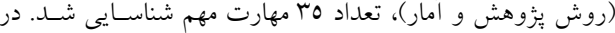

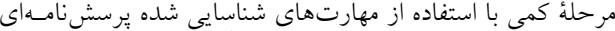

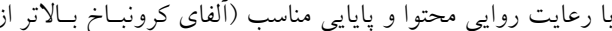

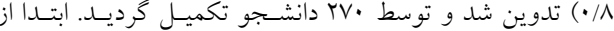

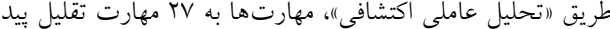

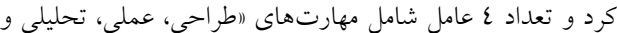

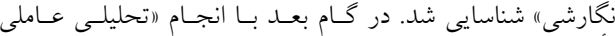

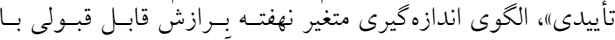

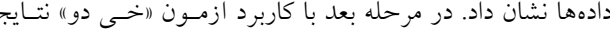

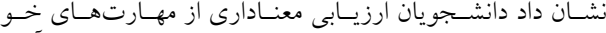

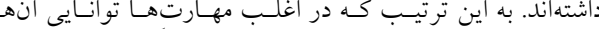

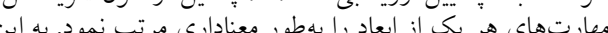

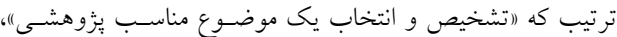

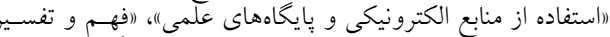

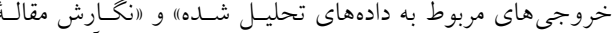

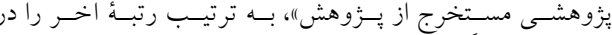

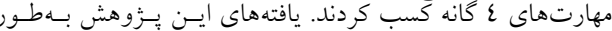

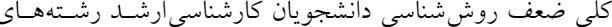

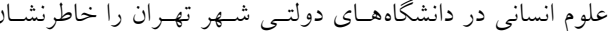

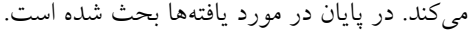
كارشناسى ارشد، علوم انسانى، مهارت، روش روش آميخته

$$
\begin{aligned}
& \text { l. }
\end{aligned}
$$

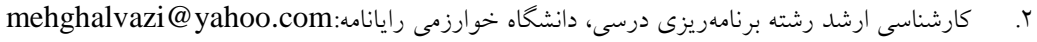

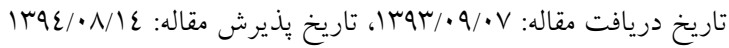




\section{مقدمه و بيان مسأله}

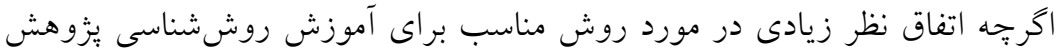

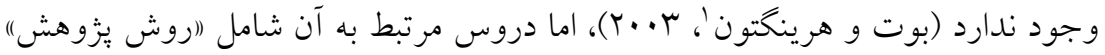

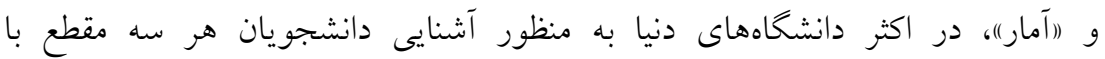

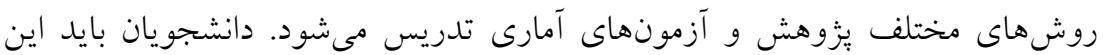

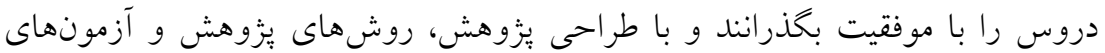

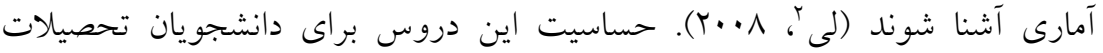

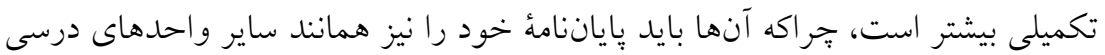

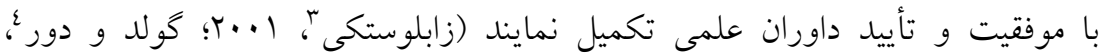

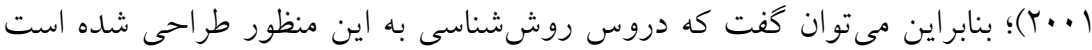

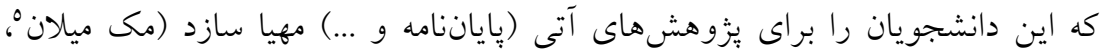

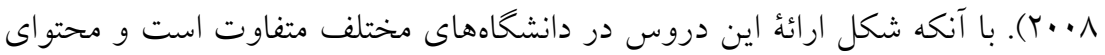

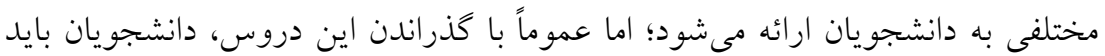

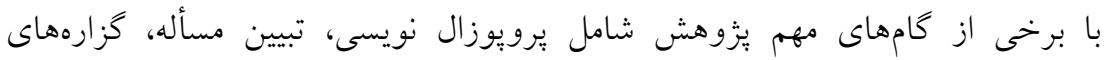

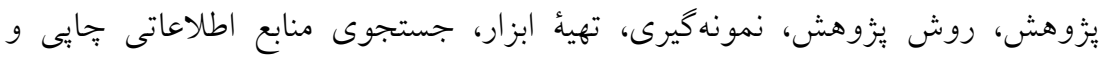

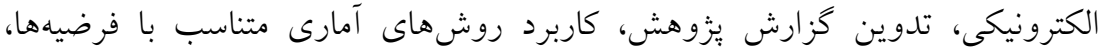

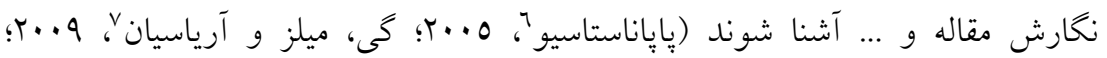

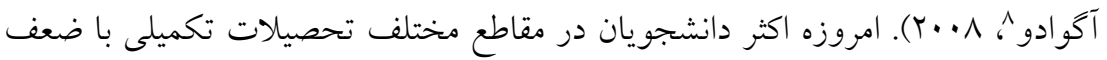

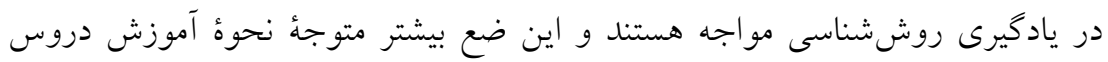

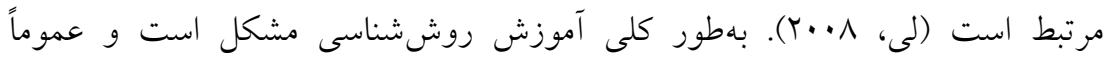

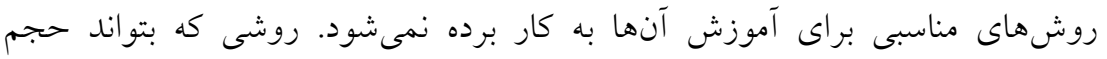

\footnotetext{
1. Booth \& Harrington

2. Lei

3. Zablotsky

${ }^{4}$. Golde \&Dore

5. McMillan

${ }^{6}$. Papanastasiou

7. Gay

${ }^{8}$. Aguado
} 
تأملى بر مهارتهاى روش شناسى بُزوهش در دانشجويان...

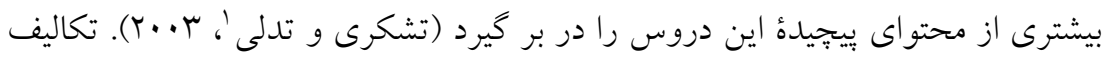
غير كالسى و كاسى، نقد يزّوهشها و مقالات، ارائهُ شفاهى، تكاليف مرتبط به تحليل دادههاى جناى متغيره و تك متغيره و تفسير بروندادهاى نرمافزارهاى آمارى (مثل

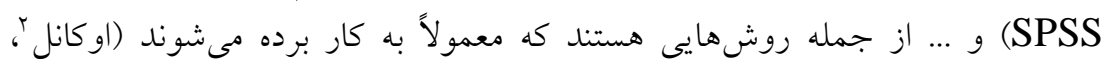

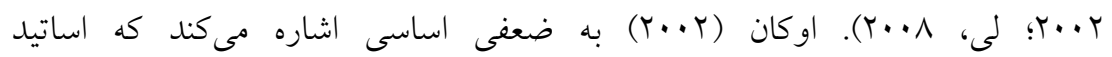
روششناسى مخاطب آن هستند. او معتقد است كه اغلب اساتيد، روش شناسى را به كونهاى تدريس مى كنند كه به تصور خود صحيح است. اين رويكرد به تدريس، حفظ يك الخوى هنجارى است كه در آن، معلم دانا است و دانشجو، يك كشتى خالى است كه در انتظار براى ير شدن است. به بيان ديخر با توجه به ماهيّت بيّيجيده اين دروس، فرايند آموزشى روشنى نيز براى آن وجود ندارد. اغلب دانشجويان مدام از اين امر

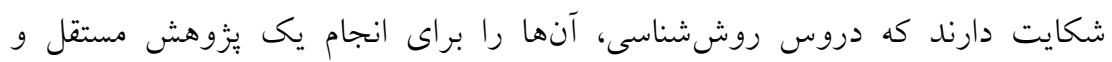
ياياننامه آماده نكرده و مهارتهاى روششناسى لازم را در در اين درس فرانكرفتهاند

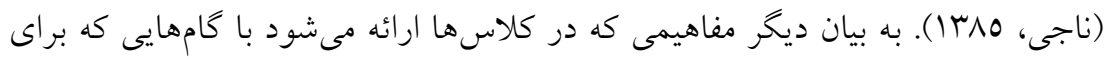

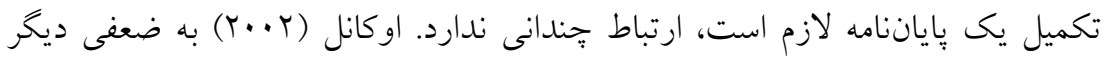
نيز اشاره مى كند و معتقد است كه ادبيات موجود بيشتر به آموزش دروس روش

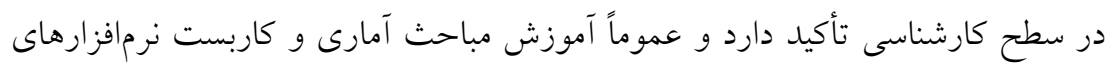
آمارى را مورد توجه قرار مىدهد. البته ناخفته نماند كه روشهاى آمارى به صورت صريح يا ضمنى، بخش مهمى از فرايند اكثر يزّوهشهاى كمى و يا آميخته هستند. دانشجويان ناگزيرند كه اصول و روشهاى آمارى را بياموزند. آنها براى تجزيه و تحليل دادههاى جمعآورى شده در رابطه با ياياننامهٔخود بىنياز از آمار نيستند

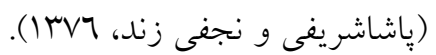

ضعفهاى برشمرده به همراه ساير ضعفهاى مرتبط به تدريس ناكافى و توجه

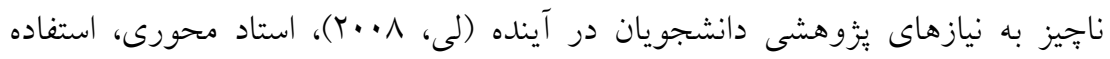
بيش از حد از روش سخنرانى، توجه ناجيز به روشهاى عملى، مشاركتى، فعال، يادگيرى مبتنى بر مسأله، كار گروهى، ايفاى نقش و شبيهسازى، عدم برقرارى تعامل

1. Tashakkori, A., \& Teddlie

2. O’Connell 


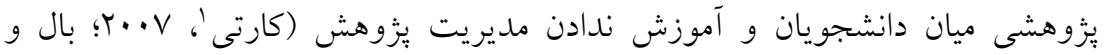

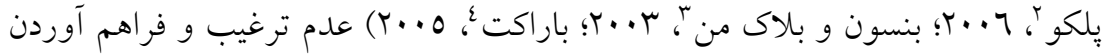

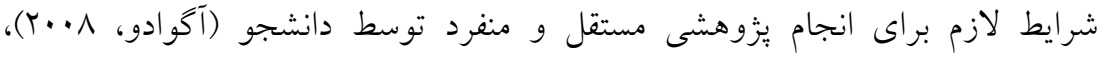

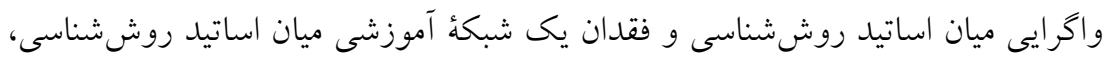

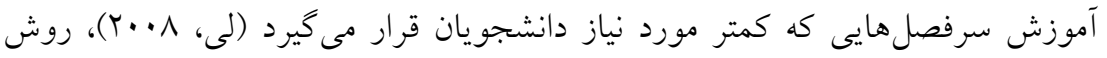

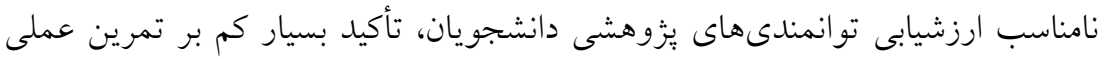
روششناسى و كم بودن اساتيد متخصص در اين حوزه، انخيزه و اعتمادبهنفس كم و

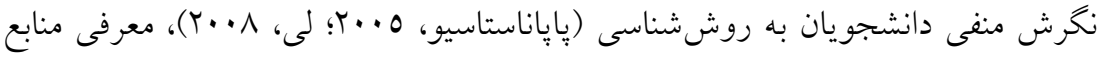

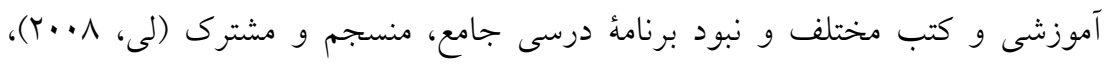

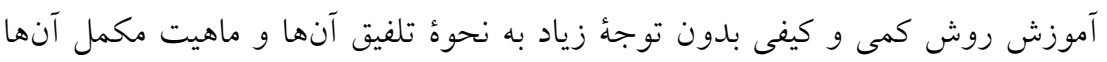

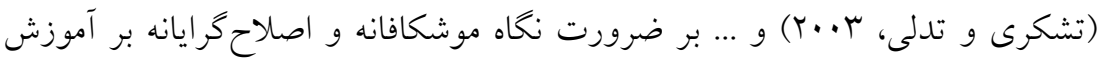
روششناسى در رشتههاى علوم انسانى در مقطع تحصيلات تكميلى افزوده است و اين

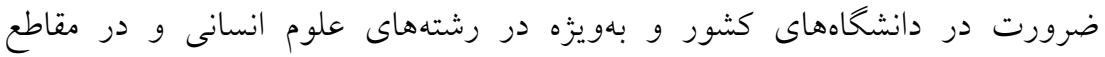
تحصيلات تكميلى بيشتر احساس مىشود. براى مثال در ايران لطف آبادى، نوروزى و

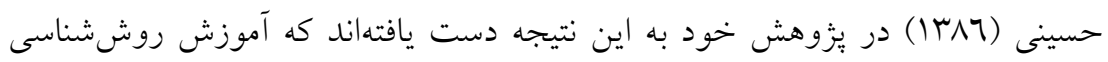

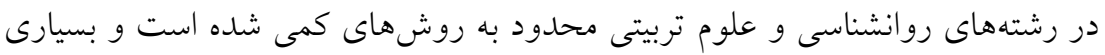

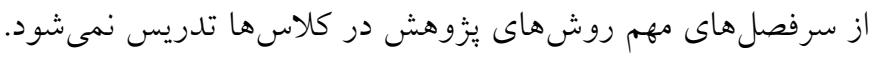

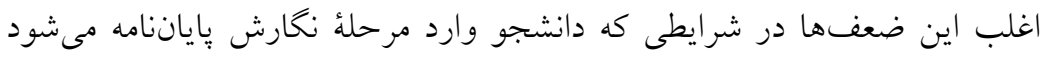

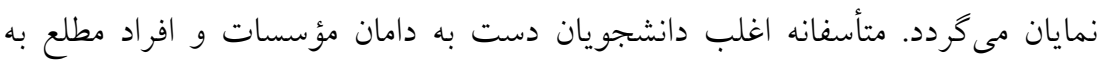
روششناسى مىشوند و برخى از اركانها و افراد سودجو نيز در اين بين روشهاى درديان

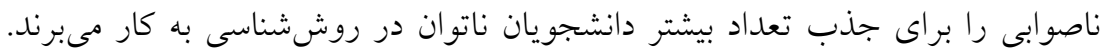

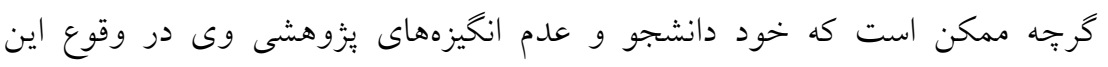

1. Carty

2. Ball \& Pelco

3 . Benson \& Blackman

${ }^{4}$. Barraket 
تأملى بر مهارتهاى روششناسى بروهش در دانشجويان...

شرايط ناكوار مؤثر باشد، اما دليل مهم ديخرى كه در اين شرايط به ذهن خطور مى كند

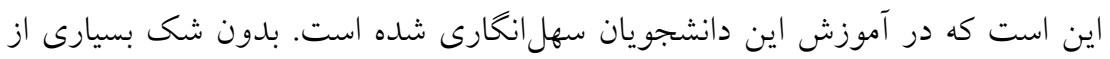

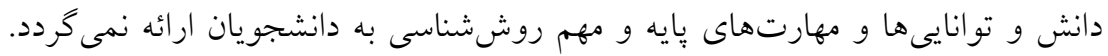

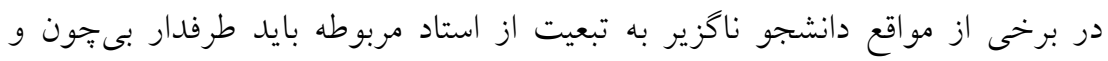

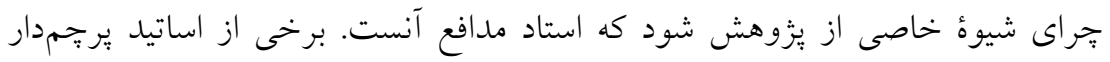

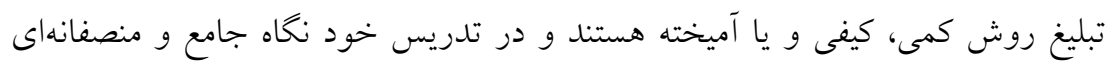

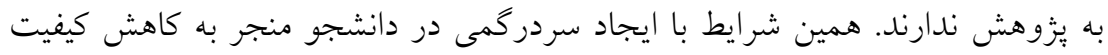

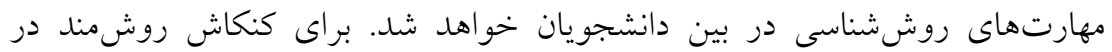

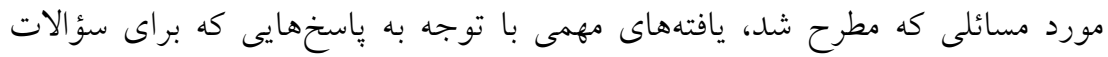
يُزوهشى ذيل فراهم شده است، به دست آمده است:

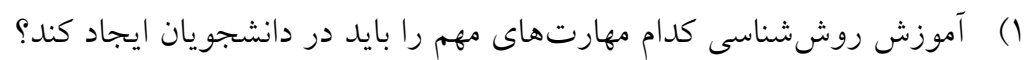

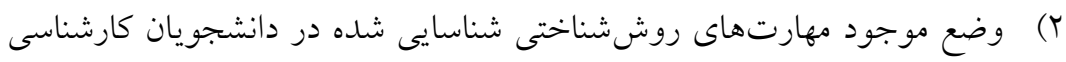

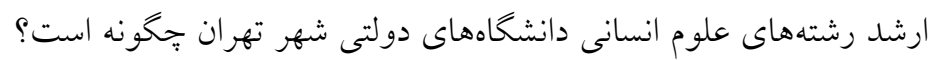

\section{روش پيزوهش}

"يزووهش حاضر به روش "(آميخته اكتشافى") انجام شده است. در اين يزوهشها ابتدا

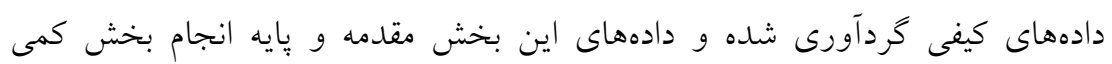

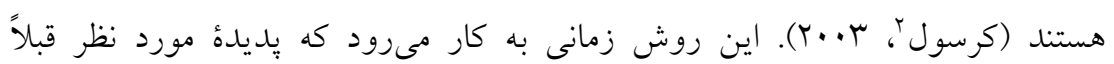

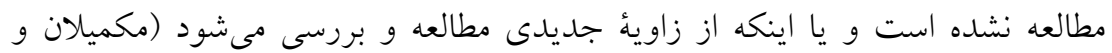

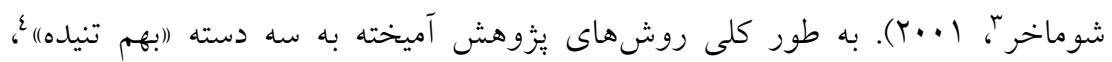

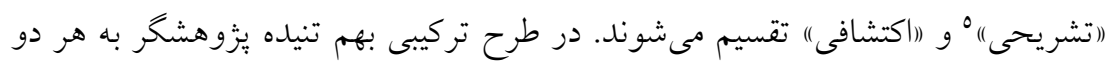

1 . Exploratory mixed-method

${ }^{2}$. Creswell

. McMillan \& Schumacher ${ }^{r}$

${ }^{4}$. Triangulation

5 . Explanatory 
مجموعة دادهاى كمى و كيفى وزن مساوى مىدهد و در طرح تركيبى تشريحى وزن

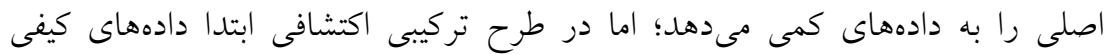

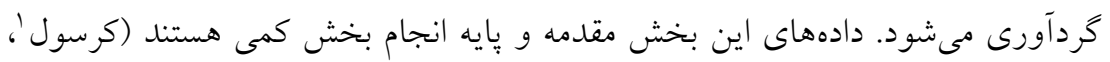

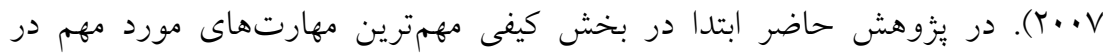
آموزش روششناسى شناسايى شده و سبس در بخش كمى وضع موجود مهارتها ارزيابى شد.

در بخش كيفى 10 استاد و يزوهشخر خبره در امر آموزش روش يثوهش و آمار به

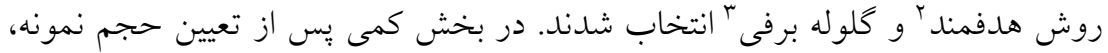

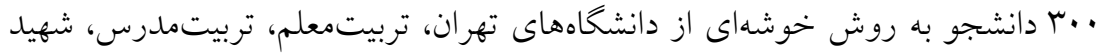

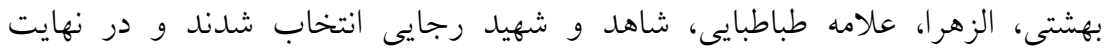
اطلاعات • rV دانشجو در رشتهاى علوم تربيتى، روانشناسى و علوم اجتماعى تحليل

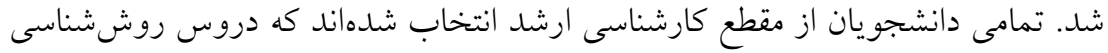

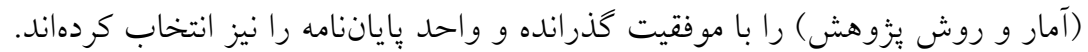
در بخش كيفى خبر كان مشاركت كننده، به صورت نيمه ساختار يافته مصاحبه شدند. در شروع هر مصاحبه ضمن برقرارى ارتباط اوليه، هدف و ييامد يزوهش تشريح شد و

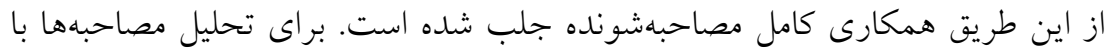

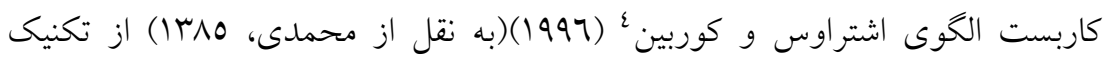
(تحليل محتو)ا) براى كد گذارى، طبقهبندى و تلخيص اطلاعات استفاده شد. ابتدا يك بار تمام مصاحبهها بررسى و مرور شد و طبقاتى براى طبقهبندى و كدكذارى محتوا تعيين شد و براى تلخيص و تشريح بيشتر براى هر طبقه، زير طبقاتى تعيين شد. در مرحلة وردأ

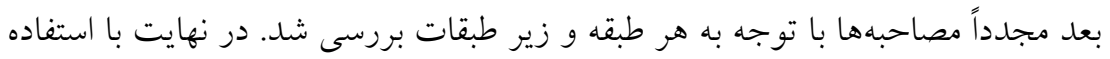

1. Creswell

2. Purposeful Sampling

3. Snowball sampling

${ }^{4}$. Strauss \& Corbin 
تأملى بر مهارتهاى روش شناسى بُزوهش در دانشجويان...

از تكنيك (رأى شمارى)' و تلفيق يا حذف موارد تكرارى، مهارتهاى مهم در آموزش روششناسى شناسايى شد. اين مهارتها مبناى تدوين برسشنامهُ يزوهش در بخش كمى بوده است. اين برسشنامه با نام (مهارتهاى روششناسى" با استفاده از مقياس درجهاى ليكرت (از / / كمترين تا ب / بيشترين) نخرشهاى دانشجويان را در مورد مهارتهايى كه در دروس روش يزوهش و آمار كسب كردهاند بررسى كرده است. لازم به ذكر است در بررسى روايى از (روايى محتوا)) و (روايى سازه)) و در بررسى بايايى از روش همسانى درونى با محاسبه (آلفاى كرونباخ)|(بين A/· تا ع9/• براى ابعاد و كل يرسش نامه) استفاده شده است. در بخش كيفى با استفاده از روش تحليل محتوا شرح توصيفى، تحليلى و ادراكى بر دادههاى حاصل از مصاحبهها، روش مناسبى براى تحليل دادههاى كيفى بوده است؛ اما در بخش كمى از روشهاى آمارى توصيفى و استنباطى (تحليل عاملى اكتشافى و تأييدى، آزمون خىدو و فريدمن) استغاده شده است. براى قضاوت در مورد كيفيت هر يك از مهارتهاى روششناختى از طيف قضاوت سه بخشى استفاده شده است. براى هر كويه و بُعد شناسايى شده ميانخين بين سب/ץ تا ا در سطح نامطلوب (با امتياز ()، بين r/77 تا ع/r بر در سطح نسبتاً مطلوب (با امتياز r) و بين 0 تا بر/ در سطح مطلوب (با امتياز r) ارزيابى شده است.

\section{يافته هاى يُّوهش}

در يّاسخ به سؤال اول يزّوهش، مهارتهاى روششناسى از تحليل محتواى مصاحبه ها و توجه به سرفصل هاى مصوّب دروس روش بزّوهش و آمار شناسايى شد. يس از هماهنكى زمان و مكان مصاحبه، از مشاركت كنند گان دربارهٔ تجارب زيستهشان در آموزش روششناسى و مهارتهاى مورد نياز دانشجويان سؤال شد. سؤالات

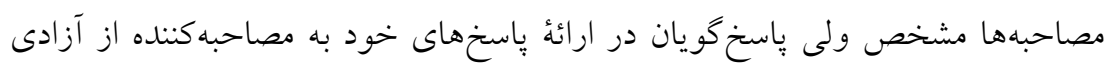

1. Vote counting 
كامل برخوردار بودند. البته يُوهشخر در حين مصاحبه علاوه بر سؤالات كلى، سؤالات

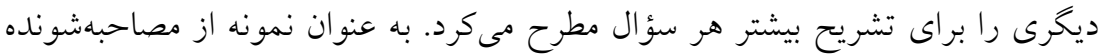

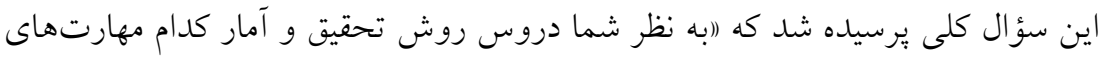

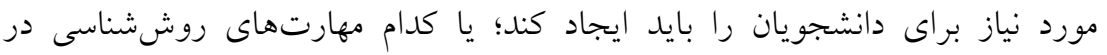
سرفصل هاى موجود ناديده كرفته شده است و استاد مربوطه بايد به آنها تأكيد كندا). ياسخهاى جمع آورى شده در صورت موافقت مصاحبهشونده به صورت صوتى دخيره شد. بس از هر مصاحبه، باسخها روى كاغذ نوشته شد و مهمترين كدهاى ذكر شده

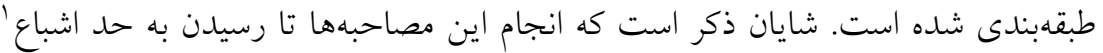

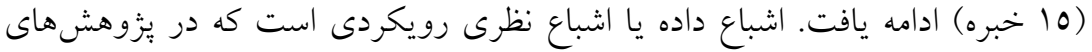
كيفى براى تعيين كفايت نمونهگيرى استفاده مىشود. يس از انجام تمام مصاحبهها و و

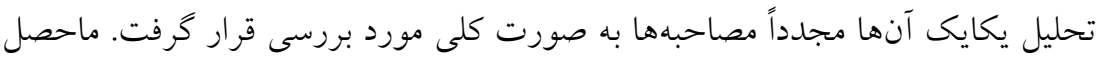
اين بررسى و رفت و بركشتها، شناسايى 9ع مهارت روششناسى براى دانشجويان

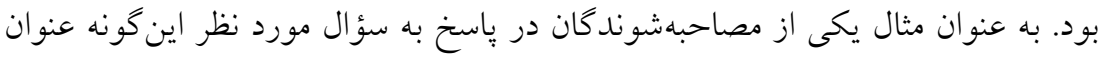

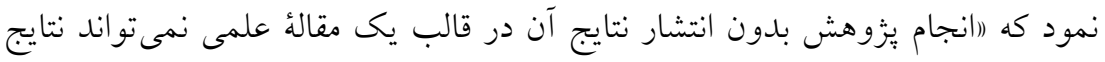

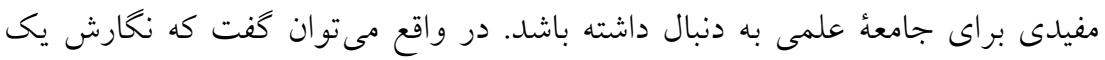

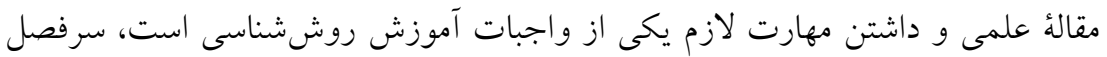

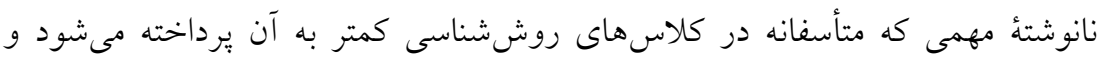

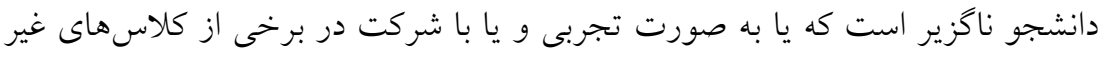

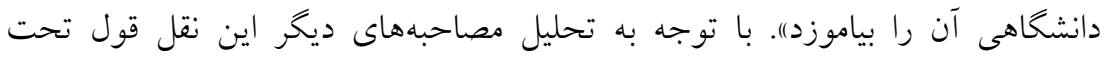

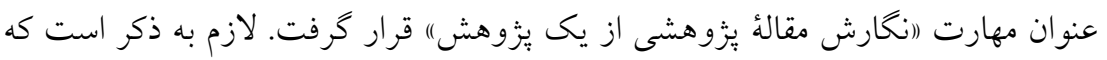

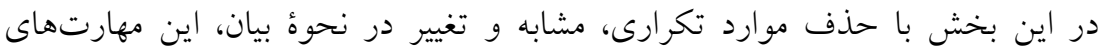

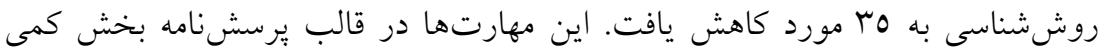

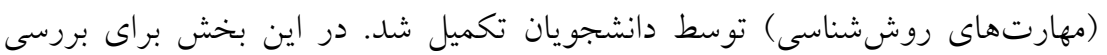

\section{Saturation}


تأملى بر مهارتهاى روششناسى بروهش در دانشجويان...

ساختار عاملى، تحليل عاملى اكتشافى با روش تحليل مؤلفههاى اصلى ' انجام شد. اندازه

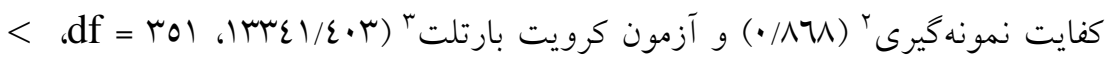

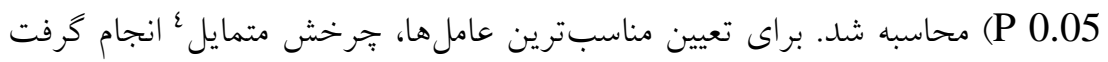

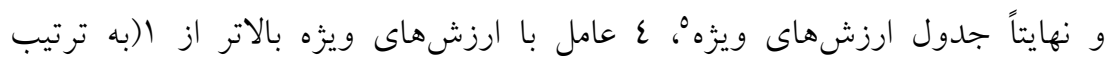

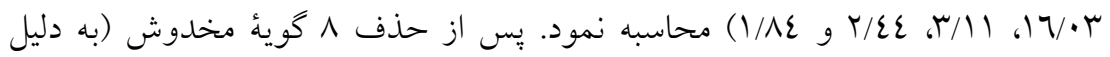

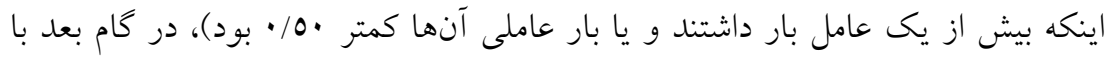

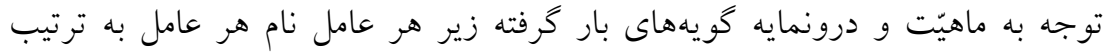
مهارت طراحى، عملى و تحليلى و نخارشى تعيين شد (شكل ()).

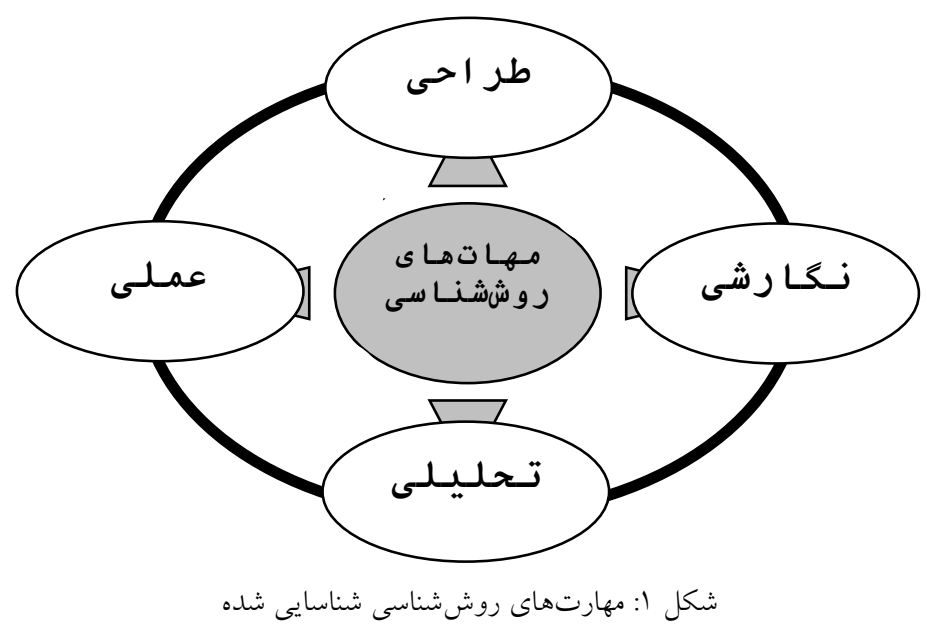

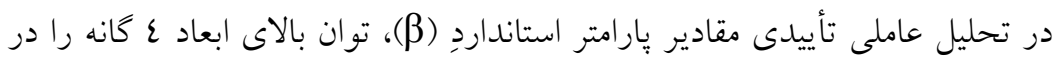
اندازهيرى متغير مهارتهاى روششناسى و همجنين توان بالاى هر كدام از نشانكرها

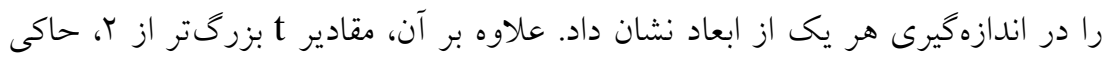

1. Principal Component Analysis

2. Kaiser-Meyer-Oliken (KMO) Measure of Sampling Adequacy

3. Bartlett's Test of Sphericity

${ }^{4}$. Oblimin rotation with Kaiser Normalization

${ }^{5}$. Eigenvalue 
از معنادارى تمام آنها بود. به علاوه تمامى شاخصهاى برازش وضعيت مناسبى را

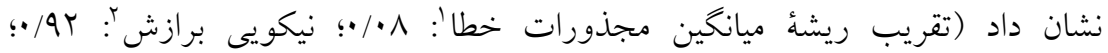

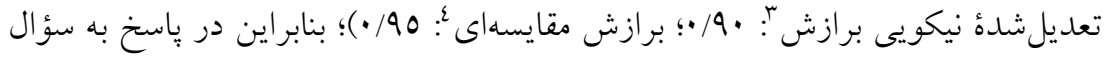

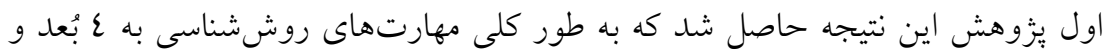

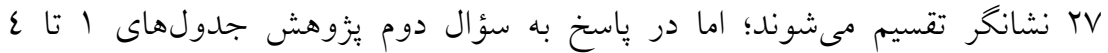
يافتههاى مهمى را كزارش كردهاند.

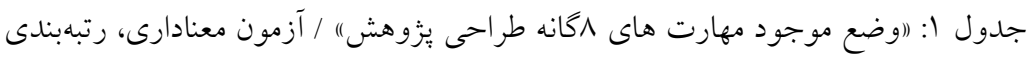
و كيفيت

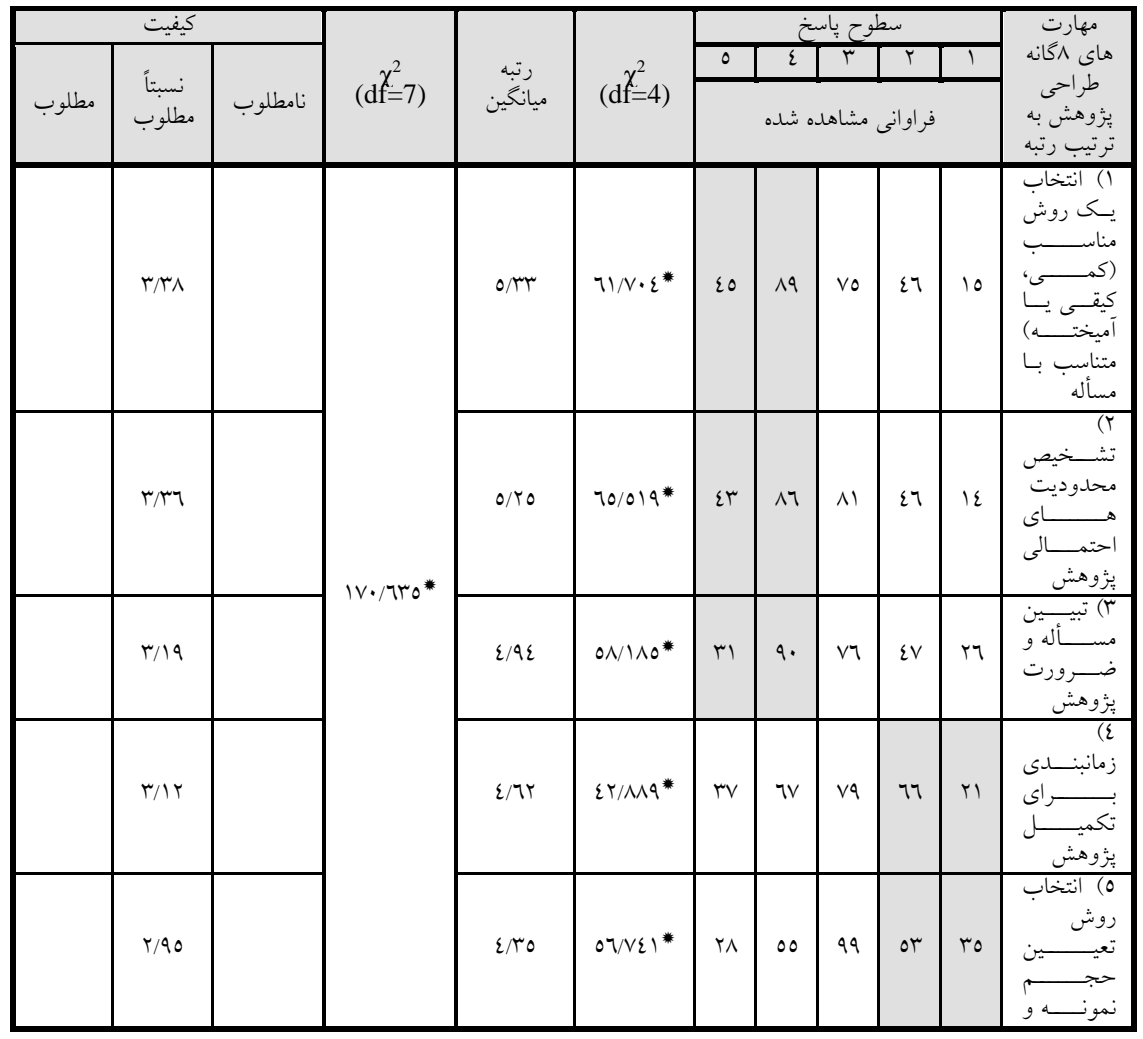

1. Root Mean Square Error of Approximation (RMSEA)

2. Goodness of Fit Index (GFI)

3. Adjusted Goodness of Fit Index (AGFI)

${ }^{4}$. Comparative Fit Index (CFI) 
تأملى بر مهارتهاى روششناسى يزوهش در دانشجويان...

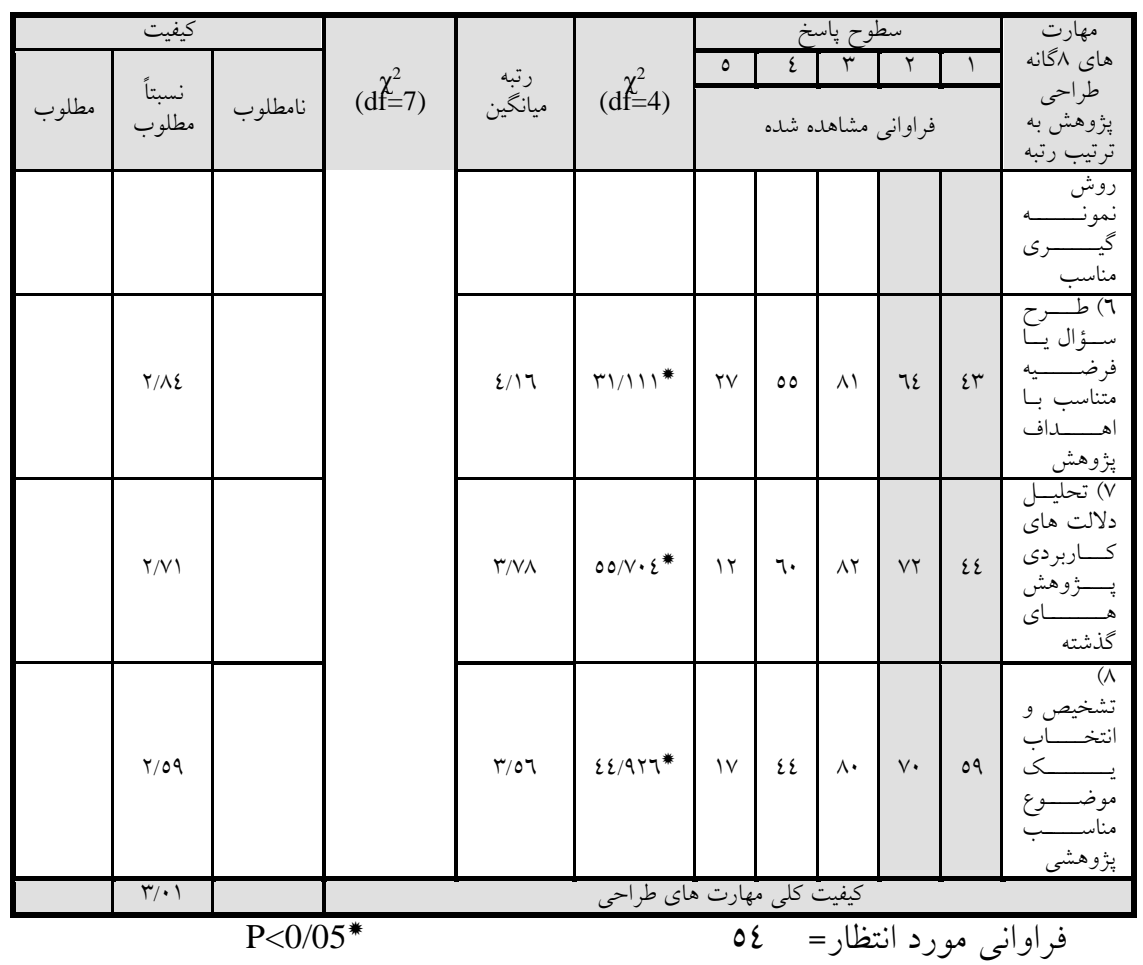

بر اساس جدول ا، دانشجويان ميزان بهرهمندى خود از هر يك از مهارتهاى 1 كانه طراحى يزوهش را به طور معنادارى ارزيابى كردهاند. علاوه بر آن اين مهارتها به ترتيب اهميت از رتبهُ اول تا هشتم مرتب شدهاند كه اين رتبهبندى نيز به لحاظ آمارى معنادار است. در بعد مهارتهاى طراحى بزّوهش، مهارتهاى ع تا م، به طور معنادارى در سطح متوسط به يايين ارزيابى شده است. همجنين تمامى مهارتها در سطح (انسبتاً مطلوب)" ارزيابى شدهاند. 
دو فصلنامه نظريه و عمل در برنامهٔ درسى، شماره 7، سال سوم، ياييز و زمستان عوبا

جدول ז: ( وضع موجود مهارت هاى ^گانه عملى يزوهش) / آزمون معنادارى، رتبهبندى و

كيفيت

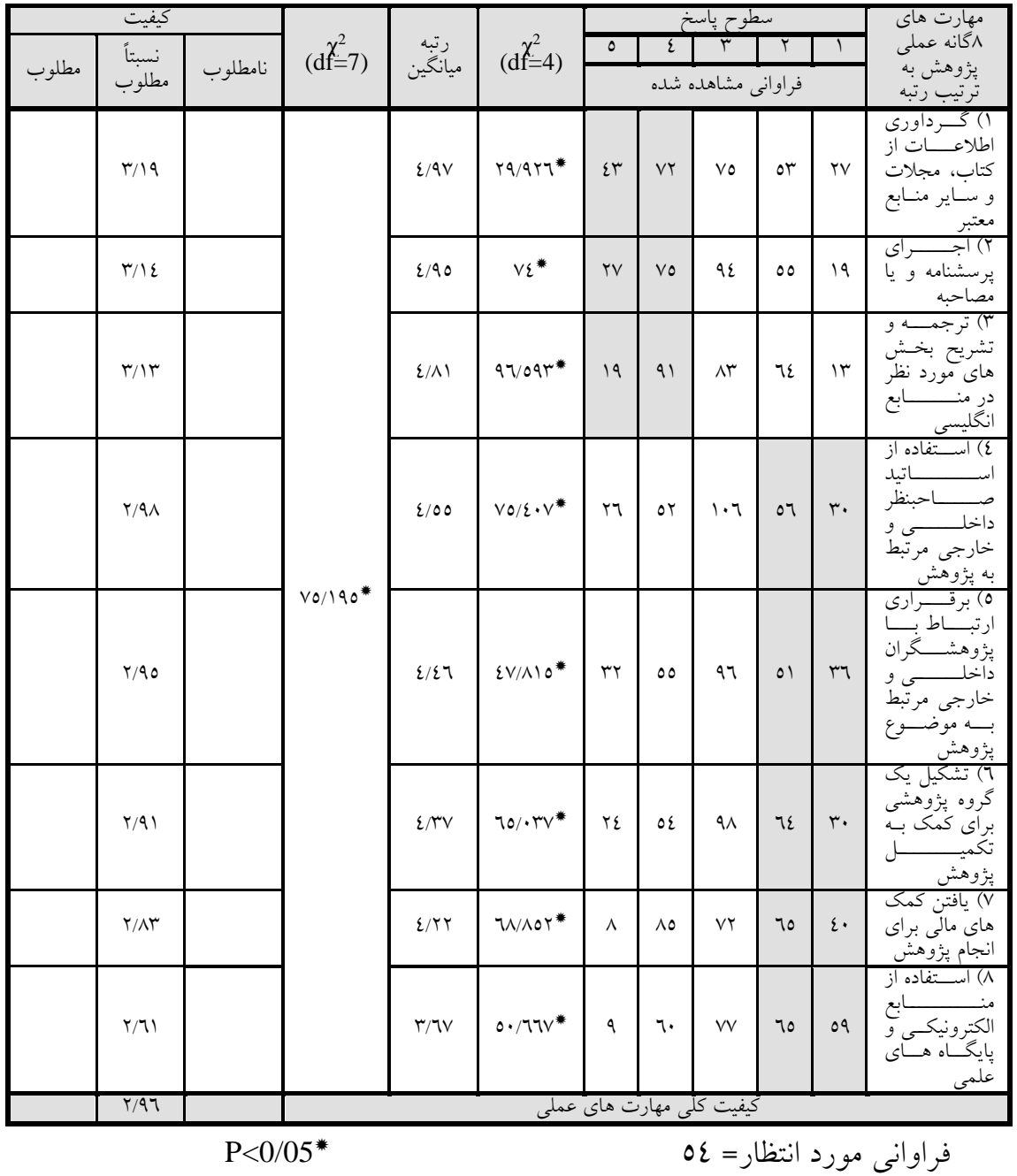

همان كونه كه در جدول r ملاحظه مىشود، دانشجويان ميزان بهرهمندى خود از هر

يك از مهارتهاى ^ كانه عملى يزوهش را نيز به طور معنادارى ارزيابى كردهاند. همجنين رتبهندى مهارتها نيز به لحاظ آمارى معنادار است. در اين بعد نيز ضمن آنكه 
تأملى بر مهارتهاى روش شناسى برُوهش در دانشجويان...

تمامى مهارتها در سطح (نسبتاً مطلوب) ارزيابى شدهاند، مهارت هاى ع تا م، به طور معنادارى در سطح متوسط به يايين ارزيابى شده است.

جدول س: (" وضع موجود مهارت هاى حكانه تحليلى يزوهش)" / آزمون معنادارى، رتبهبندى و كيفيت

\begin{tabular}{|c|c|c|c|c|c|c|c|c|c|c|c|}
\hline \multicolumn{3}{|c|}{ كيفيت } & \multirow{3}{*}{$\left(\mathrm{d}_{\mathrm{f}}^{\chi^{2}}=5\right.$} & \multirow{3}{*}{ ميانخي } & \multirow{3}{*}{$\left(\mathrm{d}^{\chi^{2}}=4\right.$} & \multicolumn{5}{|c|}{ سطوح پِاسخ } & \multirow{3}{*}{ مهارت هاى بكانه تحليلى ثروهش رتبه } \\
\hline \multirow{2}{*}{ مطلو } & \multirow{2}{*}{ مطبتًا } & \multirow{2}{*}{ ن بامطلو } & & & & 0 & $\varepsilon$ & $r$ & $r$ & 1 & \\
\hline & & & & & & \multicolumn{5}{|c|}{ فراوانى مشاهده شده } & \\
\hline & $r / \Lambda$ & & \multirow{6}{*}{$\begin{array}{l}1.1 r^{*} \\
0 \varepsilon\end{array}$} & $r / 90$ & $\begin{array}{l}\text { NET" } \\
\text { rY }^{\prime}\end{array}$ & $\begin{array}{l}\varepsilon \\
r\end{array}$ & \begin{tabular}{l|l}
$v$ \\
1
\end{tabular} & $\hat{i}$ & $\varepsilon$ & $\begin{array}{l}r \\
1\end{array}$ & رايانه كار با دادهها براى ورود انها به \\
\hline & $r / M V$ & & & r/AY & $\begin{array}{c}\pi 11 * \\
01\end{array}$ & $\varepsilon$ & $\begin{array}{l}7 \\
7\end{array}$ & $\varepsilon$ & $\begin{array}{l}\varepsilon \\
r^{\prime}\end{array}$ & $\begin{array}{l}T \\
\Lambda\end{array}$ & 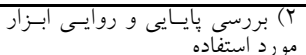 \\
\hline & $r / . \varepsilon$ & & & $r / 20$ & $\begin{array}{l}1977 " \\
91\end{array}$ & 1 & $\begin{array}{l} \\
y\end{array}$ & $\begin{array}{l}9 \\
v\end{array}$ & $\begin{array}{l}7 \\
0\end{array}$ & $\begin{array}{l}T \\
v\end{array}$ & 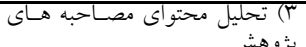 \\
\hline & $r / 91$ & & & $r / \varepsilon$. & $\begin{array}{l}\text { I乏八I* } \\
\vee .\end{array}$ & $\begin{array}{l}y \\
y\end{array}$ & $\dot{0}$ & $\begin{array}{l}q \\
\varepsilon\end{array}$ & $\begin{array}{l}v \\
r\end{array}$ & $\begin{array}{l}r \\
1\end{array}$ & 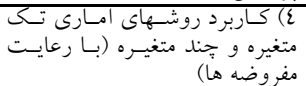 \\
\hline & $r / 9 \mathrm{~V}$ & & & $r / r 7$ & $\begin{array}{l}1 \varepsilon \cdot V^{*} \\
1 . r\end{array}$ & $\frac{1}{r}$ & $\begin{array}{l}v \\
i\end{array}$ & i & $\begin{array}{l}1 \\
\varepsilon\end{array}$ & r & 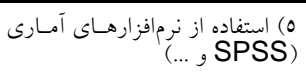 \\
\hline & T/M & & & $r / r$ & $\begin{array}{l}1 . \mathrm{rV}^{*} \\
\mathrm{~V} 7\end{array}$ & $\begin{array}{l}T_{0} \\
0\end{array}$ & $\begin{array}{l}7 \\
7\end{array}$ & $\hat{\Lambda}$ & $\begin{array}{l}\mathrm{V} \\
\Lambda\end{array}$ & $\begin{array}{l}T \\
0\end{array}$ & 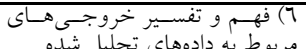 \\
\hline & $r / \cdot r$ & & & & & & 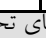 & ت & ك. & $ت$ & \\
\hline & & & & & & & & & & & كرة \\
\hline
\end{tabular}

همانند جداول ا و r، جدول شماره ب نيـز نشـان مسىدهـد كـه دانشـجويان ميـزان بهرهمندى خود از هر يك از مهارتهاى 0 كانه تحليلى يـزّوهش را بـه طـور معنـادارى ارزيابى كردهاند. علاوه بر آن اين مهارتها به ترتيب اهميت از رتبهُ اول تا بنجم مرتـب شدهاند كه اين رتبهبندى نيز به لحاظ آمارى معنادار است. در بُعد مهارتهـاى ل، ع و در سطح متوسط به يايين ارزيابى شده است. همحِنين تمامى مهارتها در سـطح (انسبتاً مطلوب)" ارزيابى شدهاند. 
دو فصلنامه نظريه و عمل در برنامهٔ درسى، شماره 7، سال سوم، ياييز و زمستان عوبا

جدول ع: ( وضع موجود مهارت هاى مكانه نخارشى يزوهش) / آزمون معنادارى، رتبهبندى

و كيفيت

\begin{tabular}{|c|c|c|c|c|c|c|c|c|c|c|c|}
\hline \multicolumn{3}{|c|}{ كيفيت } & \multirow{3}{*}{$\left(\mathrm{d} \stackrel{x^{2}}{=} 4\right)$} & \multirow{3}{*}{ ميانتخين } & \multirow{3}{*}{$\left(\mathrm{d}{\stackrel{x^{2}}{=}}_{4}\right)$} & \multicolumn{5}{|c|}{ سطوح باسخخ } & \multirow{3}{*}{ 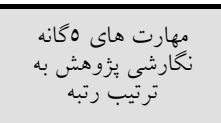 } \\
\hline \multirow{2}{*}{ مطلو } & \multirow{2}{*}{ مطنبتا } & \multirow{2}{*}{ ن بامطلو } & & & & 0 & $\varepsilon$ & & $T$ & $T$ & \\
\hline & & & & & & \multicolumn{5}{|c|}{ فراوانى مشاهده شده } & \\
\hline & $r / \bullet$ & & & r/ro & ל. & $1 \varepsilon$ & ^r & $9 \pi$ & or & r & 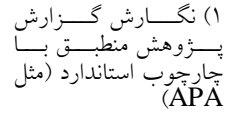 \\
\hline & $r / \cdot v$ & & & $r / r \varepsilon$ & & 11 & $\wedge \cdot$ & 91 & 70 & 17 & 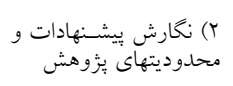 \\
\hline & $T / N \varepsilon$ & & 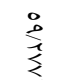 & T/AT & 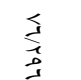 & ir & or & ᄉ. & 19 & r & r) نگارش يرويوزال \\
\hline & $T / N T$ & & & T/NA & $\begin{array}{l}\frac{1}{2} \\
\frac{1}{0} \\
\frac{0}{2}\end{array}$ & 11 & $\varepsilon v$ & $\Lambda \varepsilon$ & $\Lambda \varepsilon$ & rV & 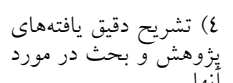 \\
\hline & $T / N \varepsilon$ & & & $T / N \cdot$ & $\sum_{*}$ & IV & ६1 & 1. & $v^{r}$ & ro & 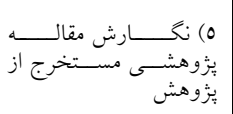 \\
\hline & $T / A V$ & & & & & كارشى & هاى نَّ & هارت & ت كلى & & \\
\hline
\end{tabular}

همان گونه كه در جدول ع ملاحظه مىشود، دانشجويان ميزان بهرهمندى خود از هر يك از مهارتهاى 0 كانه نخارشى يزّوهش را نيز به طور معنادارى ارزيابى كردهاند. همجنين رتبهبندى مهارتها نيز به لحاظ آمارى معنادار است. در اين بُعد نيز ضمن آن كه تمامى مهارتها در سطح ((نسبتاً مطلوب)) ارزيابى شدهاند، در بُعد مهارتهاى لَ، ع و 0 در سطح متوسط به يايين ارزيابى شده است. 
تأملى بر مهارتهاى روش شناسى بُزوهش در دانشجويان...

يافتههاى اين بززوهش به دليل كمبود بززوهش هاى مشابه، به ويزه در داخـل، كمتـر قابـل مواجهه و مقايسه است. در ياسخ به سؤال اول بزّوهش تعداد rV مهارت در قالب جهـار

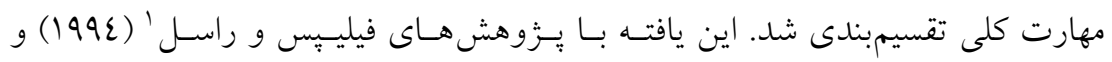

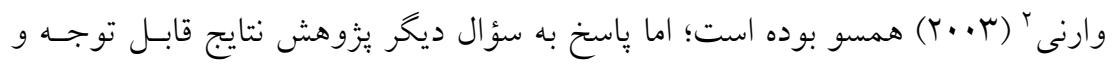
در عين حال جالش برانخيزى را به دنبال داشت. در بُعـد مهـارتهـاى طراحسى، ضـمن آن كه اغلب مهارتهاى هشت كانه بايينتر از متوسط ارزيابى شدند و وضعيت مطلـوبى نداشتند، جِند نكته مهم و قابل بحث مطرح اسـت. مهـارت (اتشـخيص و انتخـاب يـى موضوع يزووهشى مناسب) جايخاه يايينى نسبت به ساير مهارتها داشـت؛ امـا (انتخـاب يك روش مناسب (كمى، كيفى يـا آميختـه) متناسـب بـا مسـأله) رتبـهُ اول را در ميـان مهارتهاى هشت گانه كسـب نمـود. ايسن نتيجـهـ حـاكى از يـك واقعيّـت نادرسـت در كلاس هاى روششناسى به ويزه در درس روش بزّوهش مىباشـد. اغلـب كـلاسهـاى روش هاى يزووهش متأسفانه صرف آشناسازى دانشجويان با روش هاى مختلف بـزَوهش مىشود. گر جه، آشنايى دانشجويان با انواع روشها و تقسيمبندىهاى روشى مفيد اسـت

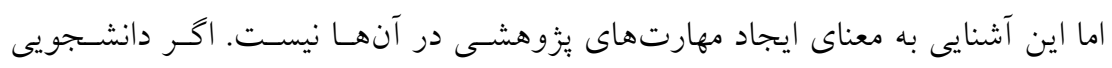

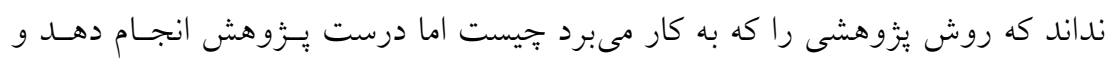
يافته هاى مهمى را فراهم كند، اين نمى تواند براى او به عنوان يكى نقص در نظر كرفتـه

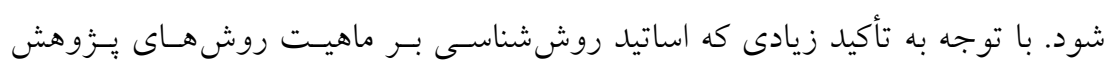
دارند، نتايج به دست آمده در ارزيابى مهارتهــاى طراحسى قابـل انتظـار اسـت. اغلـب دانشجويان در تبيين انواع روشهاى بـرّوهش و تقسـيمبنـدىهـاى مختلـف آن جـالش زيادى ندارند و تا حدى مى توانند تمايزات انواع مختلف روشها را بازگو كنــ، حتى

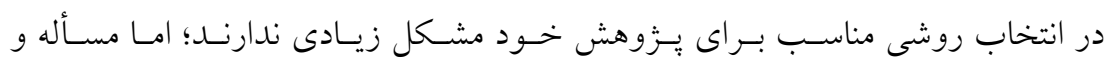
محدوديت اصلى در ساير مهارتهاى مهم طراحى بزوهش است. انتخاب روش تعيسين

1. Phillips \& Russell

2. Varney 
حجم نمونه و روش نمونه گيرى مناسب، طـرح سـؤال يـا فرضـئه متناسـب بـا اهـداف يزوهش، تحليل دلالتهاى كاربردى يزوهش هاى كذشته و تشخيص و انتخاب موضوع مناسب يزوهشى از جمله مهارتهاى مهمى بودند كه دانشجويان توانايى خود را در هر يك از آنها كمتر از متوسط ارزيابى كردند. آنجهه كه در اين بين بسيار جـاى تأمـل دارد اين است كه مهارت (تشخيص و انتخاب يك موضوع يثوهشى مناسب)) يايين ترين رتبه را در ميان ساير مهارتها كسب كرده است. انتخاب موضوع يثوهش يكى از مهمتـرين مراحل يزوهش علمى و از دشوارترين آن به شمار مسىرود (بـوت، كلمـب و ويليـامز'، 1990). انتخاب و تنظيم موضوع بزوهش، از آن دست مسائل مهمى اسـت كـه نيـاز بــه تأكيد بيشتر دارد، جون هيج نوع فعاليت بززوهشى مثبتى را نمسىتسوان صسورت داد مخـر آن كه موضوع آن، از بيش مشخص، معين و روشن كرديلده باشد. يكسى از دغدغـهــاى دانشجويان تحصيلات تكميلى انتخاب موضوع يزوهش براى نخارش يايـاننامـه اسـت. اين انتخاب تصميمى مهم و سرنوشتساز است. جرا كه ميزان موفقيت دانشجويان ايسن

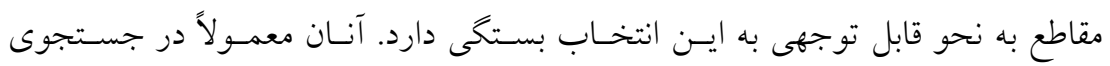
موضوعهاى تازه و اصيل براى يزٔوهش خود هستند و از تكــارى بــودن موضـوع خـود نخراناند. اين نخرانى زمانى براى آنها بيشتر مىشود كه دربارهُ تقريباً هر موضـوعى كـهـ جستجو مى كنند خود را با دهها يا صدها اثر منتشر شده مواجه مىبينتـد. كـويى دربـاره: همه جِيز قبلاً بزّوهش شده است و ديخر موضوع تازهاى باقى نمانده است (منصـوريان،

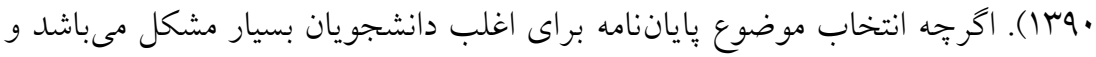
كاهى اوقات انتخاب موضوع تا ترمهاى يايانى طول مى كشد و اين امر موجب به تـأخير

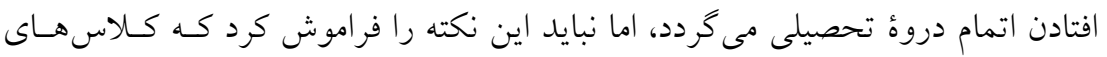
روششناسى و اساتيد مربوطه كمتر به اين مبحث بسيار مهم و كليدى براى دانشسجويان مى يردازند. اين در حالى است كه دانشجو بايــا بـا شـيوههـاى مفيــ انتخـاب موضـوع يُزوهش آشنا باشد. همجينين بهتر است كه دروس روش شناسى توسط اساتيدى آشنا بـهـ روش و داراى سوابق علمى و بثوهشى بالا تدريس شود كه علاوه برايجاد مهارتهـاى

\section{${ }^{1}$. Booth, Colomb \& Williams}


تأملى بر مهارتهاى روششناسى بروهش در دانشجويان...

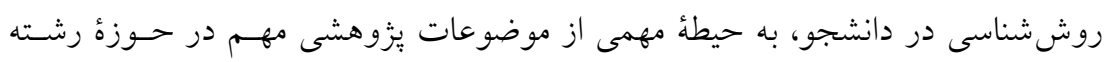

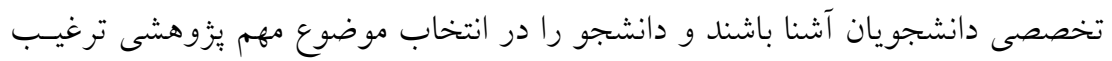

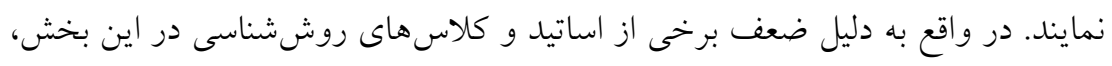
اين يافته كه مهارت انتخاب يكى موضوع مناسب كمترين ارزيابى را داشـته قابـل انتظـار بوده است.

در مهارتهاى عملى نكتهٔ مهم اينست كه دانشجويان خود را در (استفاده از منابع الكترونيكى و بايخاههاى علمى" ناتوانتر از ساير مهارتهاى بهاى برشمرده ارزيابى كردهاند.

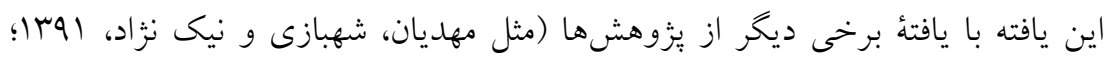

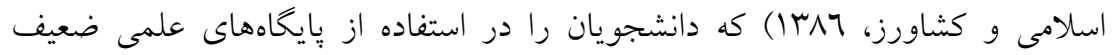

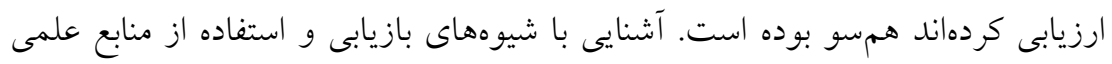

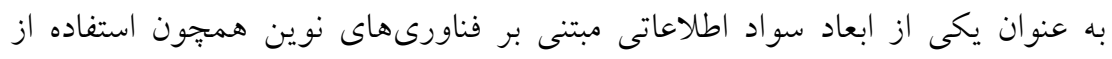

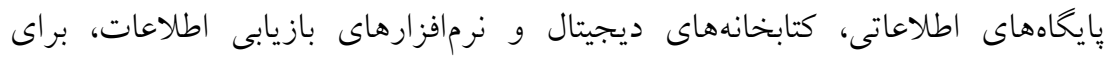

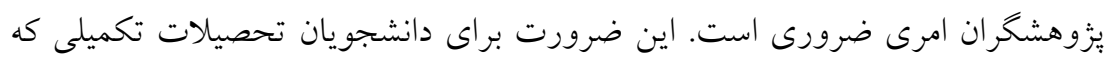

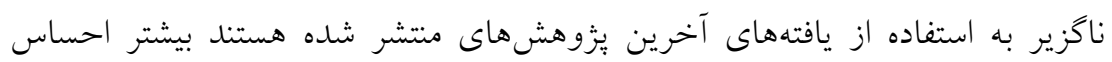

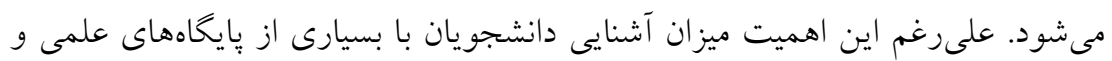

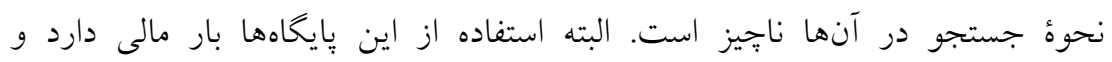

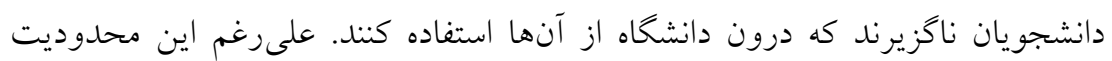

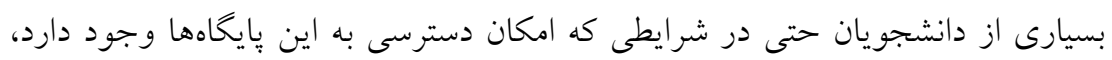

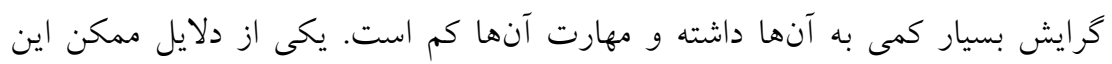

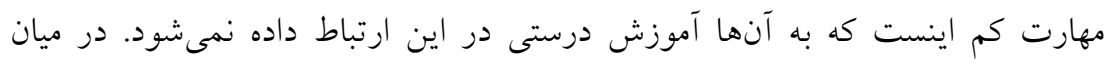

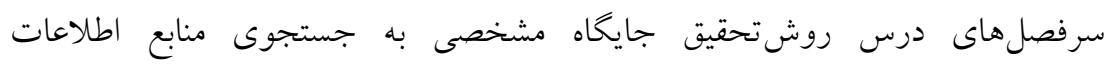

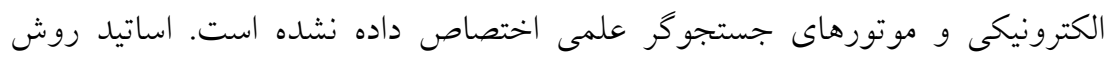

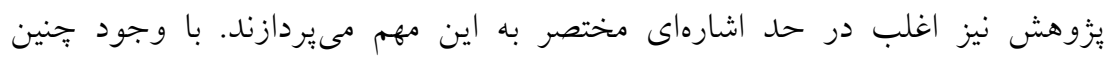

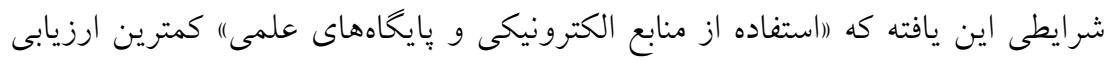
را در دانشجويان داشته قابل انتظار بوده است. 
يافتهاى مربوط به ارزيابى مهارتهاى تحليلى نكات قابل بحثى را به دنبال دارد.

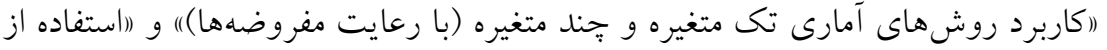

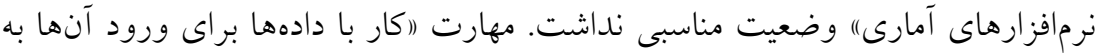

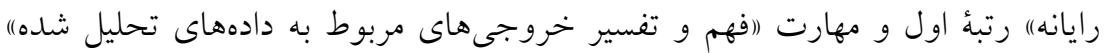

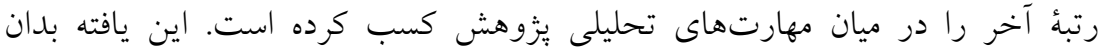

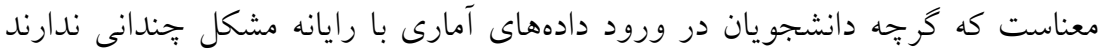
اما مشكل اساسى آنها در تفسير بروندادهاى دادهاى تحليلى شده است. تجارب نشان

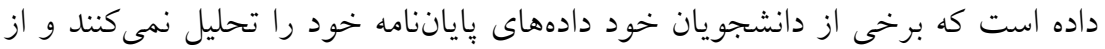

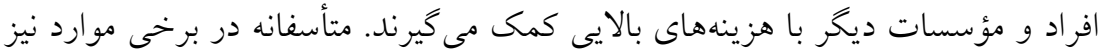

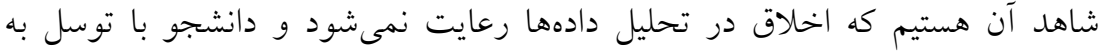
شيوههاى غير علمى و دادهازى غير اخلاقى دادههاى بايانانامُ خود را تحليل مى كنند.

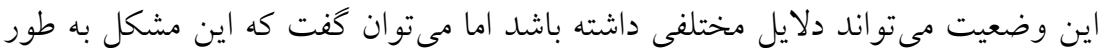

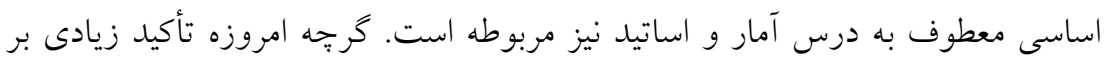

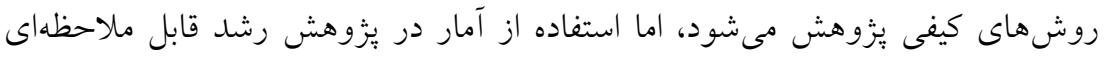

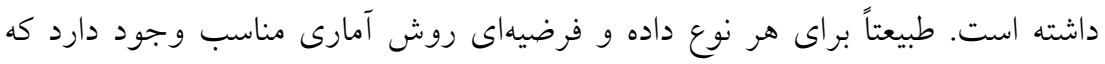

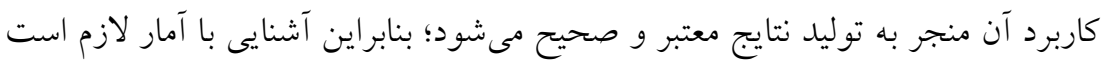

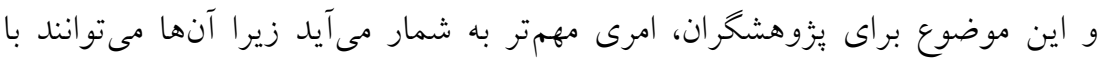

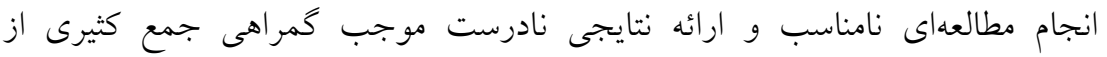

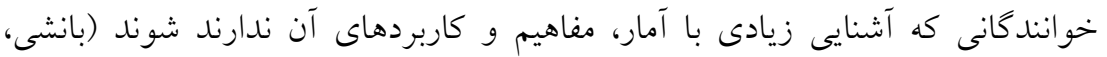

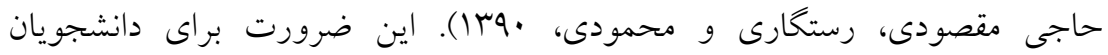

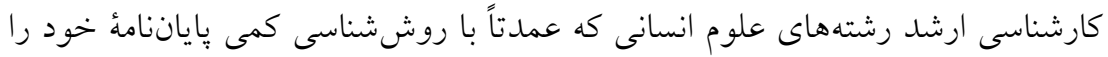

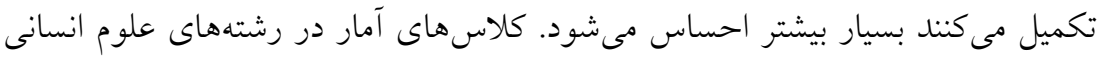

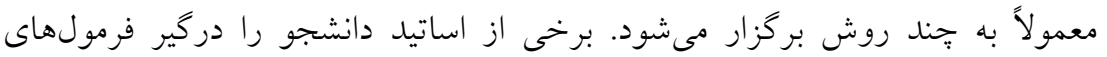

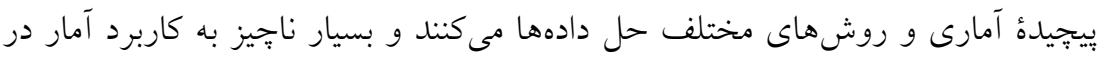

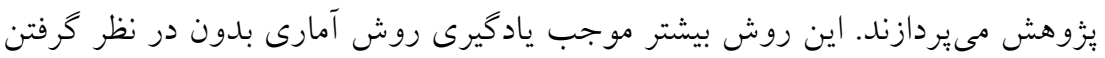


تأملى بر مهارتهاى روششناسى بروهش در دانشجويان...

كاربرد آن مىشود. برخى ديخر از اساتيد برعكس عمل نموده و صرفاً به تبيين

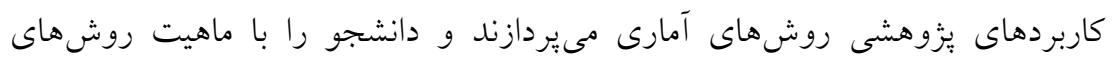

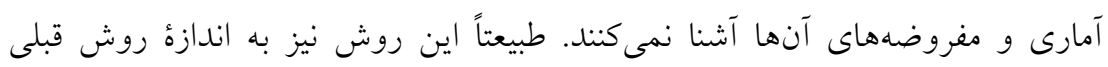

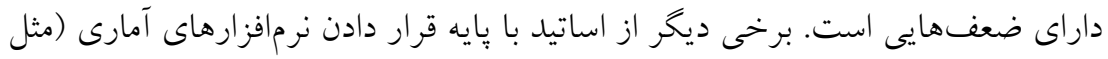

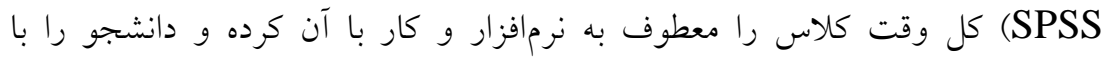

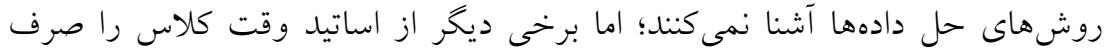

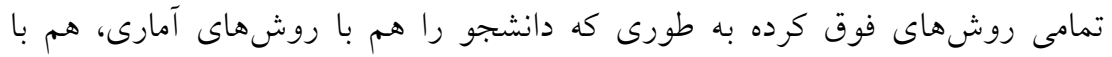

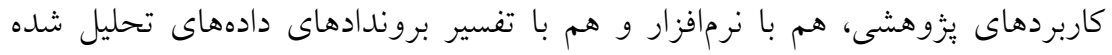

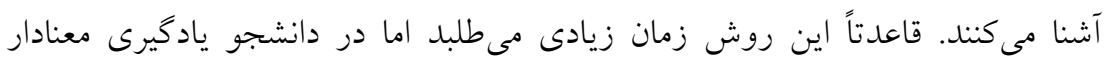

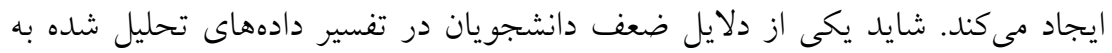

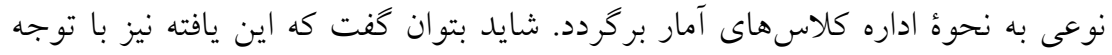

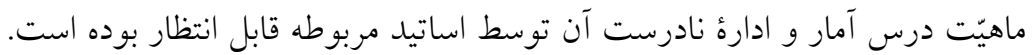

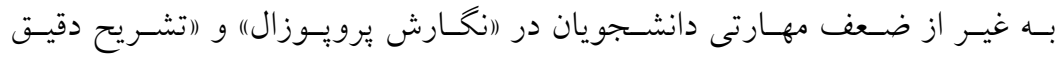

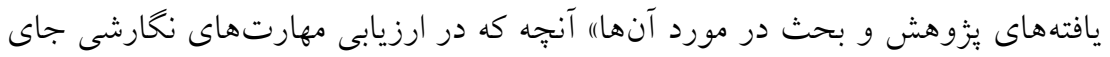

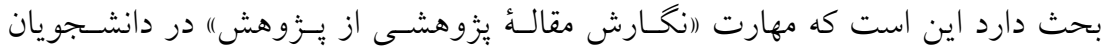

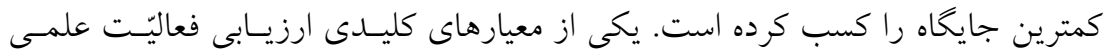

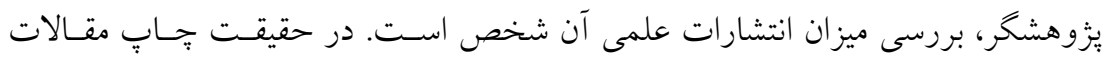

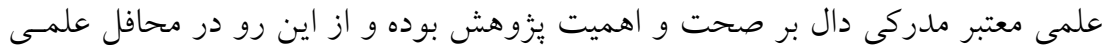

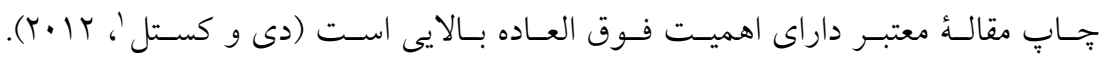
دانشجويان تحصيلات تكميلى در طى تحصيل متون مختلفى را مىنويسند. با ايسن حسال

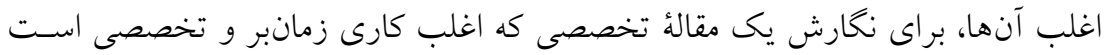

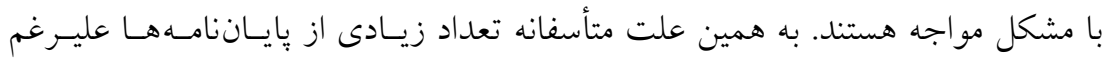

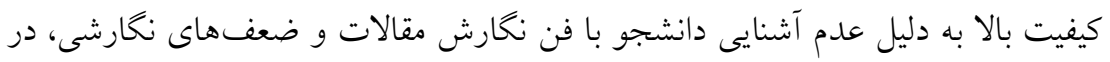

1. Day \& Gastel 
مجلات معتبر به جاب نمسىرسـند. در دانشـاههـا معمـولاً آمـوزش رسـمى در مـورد

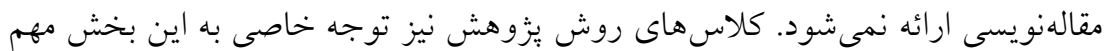

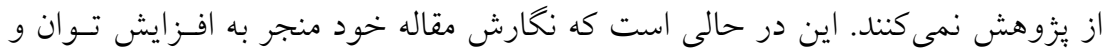

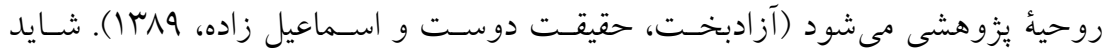

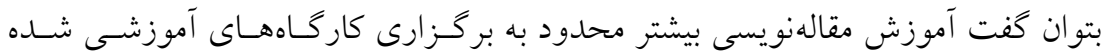

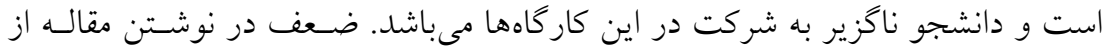
يكى سو و اهميت و ارزش مقاله براى ادامة تحصيل در مقطع دكتـراو سـاير امتيـازات

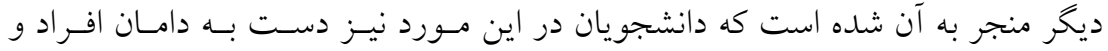

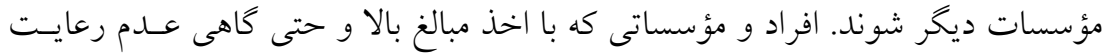

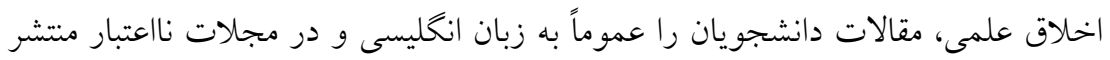
مى كنند. يكى از دلايل مهم اين وضعيت اينسـت كـه دانشـجو در درس روش يـزّوهش

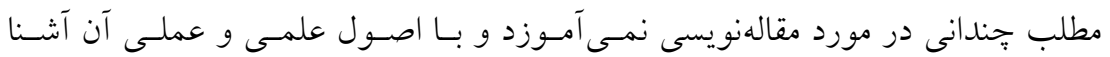

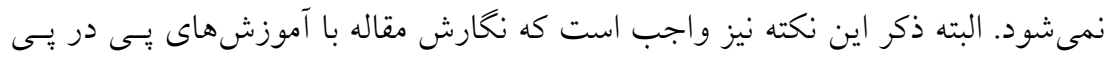
امكانيذير نيست و به نبوغ و خلاقيت دانشجو نيز بستكى دارد؛ اما على رغم ايـن عامـل فئل

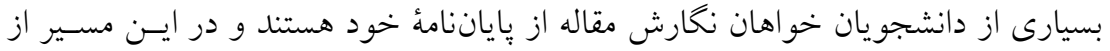

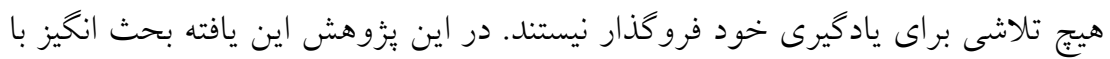
توجه به اينكه دانشجويان آموزش خاصى در مورد نوشتن مقاله نمسىبينـــ قابـل انتظـار بوده است.

يافتهاى بززوهش حاضر در مجمـوع حـاكى از ضـعف مهارتى (طراحسى، عملى،

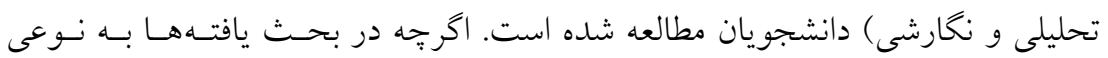

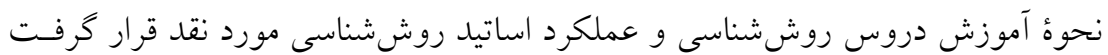

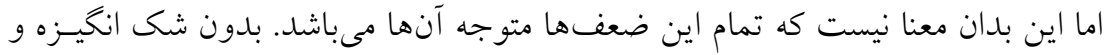

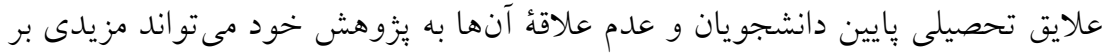

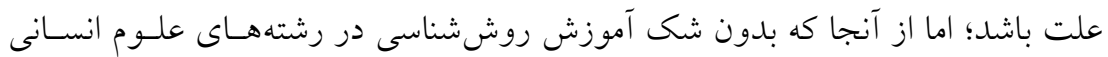

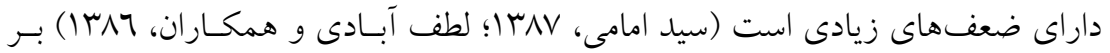


تأملى بر مهارتهاى روش شناسى بُزوهش در دانشجويان...

اين اساس شايد بىراه نباشد كه بسيارى از ضعفـهاى مهارتى دانشجويان را به آمـوزش روش شناسى و اساتيد مربوطه نسبت داد. حتى اخر اين ادعا مورد يذّيرش قرار نخيرد باز

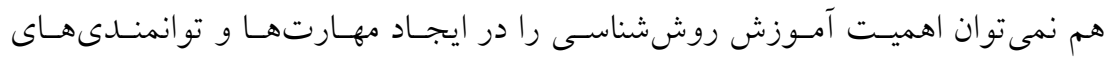
يزوهشى در دانشجويان منكر شد؛ بنابراين تلويحات كـاربردى يـزّوهش حاضـر بيشـتر نظام دانشخاهى، اسـاتيد روششناسـى و دروس روش شناسى را مـورد مخاطـب قـرار مى دهد. به طور حتم سرفصلهـاى دروس روششناسـى احتيـاج بـهـ بازانديشسى دارد و ضرورت دارد كه با انجام يُوهشى مناسب در اين سرفصل ها تجديد نظر صورت يذيرد. دانشجويان مطالعه شده در مواردى ضعف داشـتند كـه اغلـب در سرفصـل هـاى دروس روش شناسى كمتر به آنهـا ٍِرداختـه شـده اسـت. دوم آنكـه ضـرورت دارد در نحـوهُ آموزش روش شناسى نيز تغييراتى صورت يذيرد. تدريس مواردى كه مهم نيست و كمتر به كار دانشجو مى آيد و همجنين كاربست رويكرد عملى بـه آمـوزش روش شناسسى از واجبات است. بدون شك اغلب كلاسهاى روش شناسى محدود به ذكر مفـاهيم نظـرى

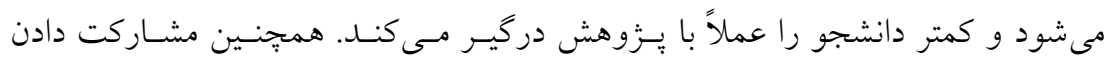
دانشجويان در كارهـاى يزووهشى مستقل و گروهـى اسـاتيد راهكـار مهمسى در ايجـاد

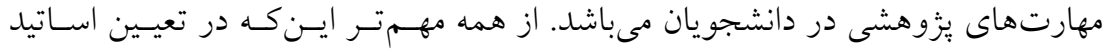
روششناسى براى تدريس دروس روش بيزوهش و آمار دقتانديشى صـورت يــيرد. اساتيدى اين دروس را تدريس كنند كه علاوه بر احاطهُ كامل به حوزهُ تخصصسى رشـته و دانشجويان، آشنايى كاملى با روش شناسى تجارب يزوهشى غنى نيز داشته باشند. 


\section{فهرست منابع}

اسلامى، عباس و كشاورز، حميد. (1) (1). بررسى مهارت جستجوى اطلاعات در

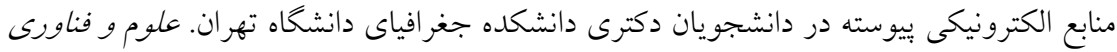

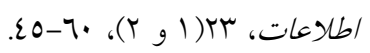

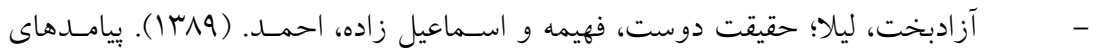

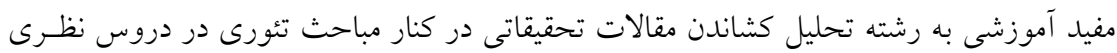

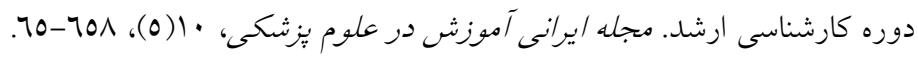

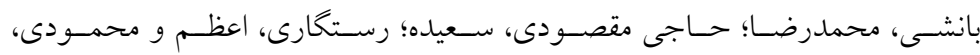

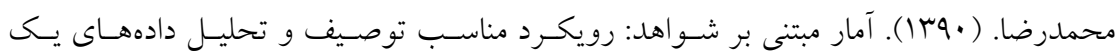

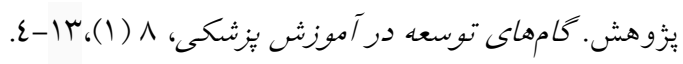

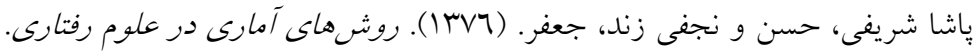
تهر ان، انتشارات سخن.

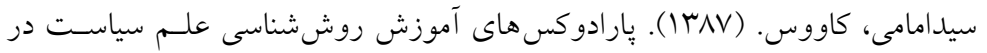

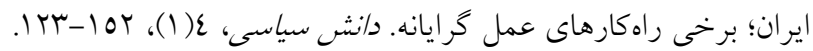

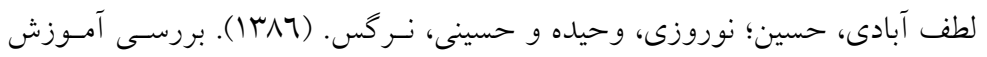

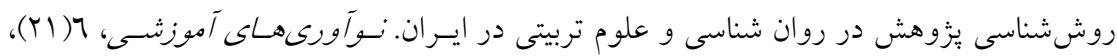
$.12 \cdot-1 \cdot 9$

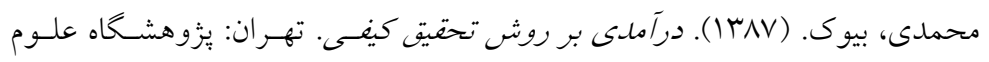

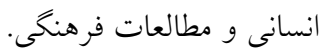

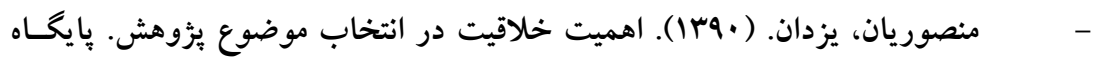

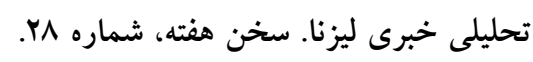

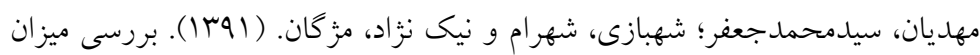

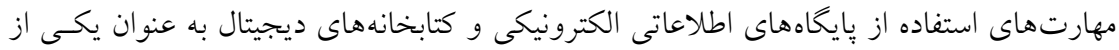

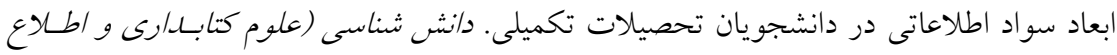
رسانى و فناورى /طلاعات)، (IV))، (1V-79.

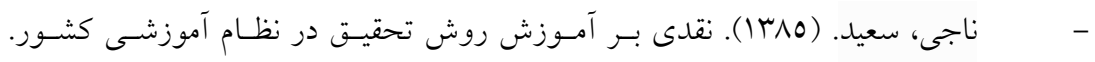




\section{تأملى بر مهارتهاى روششناسى بزُوهش در دانشجويان...}

- $\quad$ Aguado, N. A. (2009). Teaching research methods: Learning by doing. Journal of Public Affairs Education, 15(2), 251-260.

- $\quad$ Ball, C. T., \& Pelco, L. E. (2006). Teaching research methods to undergraduate psychology student using an active cooperative learning approach. International Journal of Teaching and Learning in Higher Education, 17(2), 147-154.

Barraket, J. (2005). Teaching research method using a studentcentered approach? Critical reflections on practice. Journal of University Teaching \& Learning Practice, 2(2), 65-74.

Benson, A., \& Blackman, D. (2003). Can research methods ever be interesting? Active Learning in Higher Education, 4(1), 39-55.

- $\quad$ Booth, C. \& Harrington, J. (2003). Research methods modules and undergraduate business research: an investigation. International Journal of Management Education, 3 (3), 9-31.

- $\quad$ Booth, W. C., Colomb, G. G., \& Williams, J. M. (1995). The craft of research. Chicago: University of Chicago Press.

- Brew, A. (2001). The nature of research: Inquiry in academic contexts. London: Routledge Falmer.

- $\quad$ Carty, R. (2007). Teaching Research Methods: a pragmatic approach. Investigations in University Teaching and Learning, 4(2), 98-105.

- Creswell, J. W. (2003). Research design: Qualitative, quantitative, and mixed approaches. Thousand Oaks, CA: Sage.

- $\quad$ Day, R., \& Gastel, B. (2012). How to write and publish a scientific paper. Cambridge University Press.

- $\quad$ Gay, L. R., Mills, G. E. \& Ariasian, P. (2009). Educational research: Competencies for analysis and applications. Upper Saddle River, NJ: Pearson.

- $\quad$ Golde, C. M., \& Dore, T. M. (2001). At cross purposes: What the experiences of today's doctoral students reveal about doctoral education. Philadelphia: Pew Charitable Trusts.

- $\quad$ Lei, S. A. (2008). Factors Changing Attitudes of Graduate School Students toward an Introductory Research Methodology Course. Education, 128(4), 667-685.

- $\quad$ McMillan, J. H. (2008). Educational research: Fundamentals for the consumer (5th ed.). Boston, MA: Pearson/Ally and Bacon.

- $\quad$ McMillan, J. H., \& Schumacher, S. (2001). Research in education: A conceptual introduction, 5th edition. New York: Adison Wesley Longman, Inc.

- O'Connell, A. A. (2002). Student perceptions of assessment strategies in a multivariate statistics course. Journal of Statistics Education, 10(1). [online].

- $\quad$ Papanastasiou, E. C. (2005). Factor structure of the attitudes toward research scale. Statistics Education Research Journal, 4(1), 16-26.

Phillips, J. C., \& Russell, R. K. (1994). Research self-efficacy, the research training environment, and research productivity among graduate 
دو فصلنامه نظريه و عمل در برنامة درسى، شماره 7، سال سوم، ياييز و زمستان عهب|

students in counseling psychology. The Counseling Psychologist, 22(4), 628641.

Tashakkori, A., \& Teddlie, C. (2003). Issues and dilemmas in teaching research methods courses in social and behavioural sciences: US perspective. International Journal of Social Research Methodology, 6(1), 61-77.

Varney, J. (2003). A study of the relationships among doctoral program components and dissertation self-efficacy on dissertation progress. Ed.D. dissertation. Aurora University, Aurora, Illinois.

Zablotsky, D. (2001). Why do I have to learn this if I'm not going to graduate school? Teaching research methods in a social psychology of aging course. Educational Gerontology, 27(7), 609-622. 